\title{
Middlefield: The Development of a Provincial Post-World War Two Council Estate in Lincolnshire, 1960-1965
}

\author{
IAN WAITES \\ University of Lincoln, UK
}

Scholarly, local-historical, studies of provincial, low-rise post-World War Two council estates are rare. This article attempts to remedy this by examining one such example, the Middlefield Lane estate in Gainsborough, Lincolnshire, which was completed in 1965 . Using two key primary sources, the minute books of the Gainsborough Urban District Council's Housing Committee and the Gainsborough Evening News, the article will provide a narrative account of the planning and development of Middlefield, and of the experiences of the estate's new residents as they settled in there. Postwar council estates have long been criticized as being socially and architecturally problematic. This article aims to present a more nuanced historical perspective on this by demonstrating that these estates were carefully and thoughtfully planned, and have rich and meaningful histories that are worth chronicling.

KEYWORDS council estate, Gainsborough, housing, social history, architecture, 19605

On Tuesday 9 July 1963, Marcus Kimball, Member of Parliament for Gainsborough in Lincolnshire, spent the day in the town with officials from the Gainsborough Urban District Council surveying what he described as 'the drive against the slums, to house people in decent homes'. Kimball started his day by inspecting some of the town's slum housing, which consisted of densely populated late-eighteenth- or earlynineteenth-century yards and terraces that tended to be named after the townspeople who built them (for example 'Popplewell's Row' and 'Barnaby's Yard') and which, by that time, had already been scheduled for demolition. From there, Kimball moved on to the site of a projected new housing estate on the outskirts of the town that was intended to re-house many of the occupants of those slums. Amongst what the local newspaper, the Gainsborough Evening News, described as 'bulldozers, tractors and 
other equipment at work on this the first day of the commencement of the building programme', Kimball met executives of Wimpey, the building contractors who had 'promised to complete the new housing project' of ' 380 houses, garages, shops, flats and community centre' in '2 I months'. ${ }^{\mathrm{I}}$

Wimpey were as good as their word. In May 1964, less than a year after Kimball's visit, the first residents were able to move into their new homes on what became known as the Middlefield Lane estate. Like all local authority generated estates at this time, Middlefield was a product of post-World War Two central and local government policy that intended to provide new, good quality, rented housing for workingclass families. As the war was drawing to a close it was being predicted that the country would need up to four million new houses; just a few years later, in I95I, it was estimated that up to eight million existing homes in Britain remained unfit for habitation. ${ }^{2}$ Even as the I960s dawned, the speed with which estates like Middlefield were built characterized the ongoing and urgent need for new housing.

Gainsborough was a small, provincial market town at the start of the I960s, with a population of around 17000 people. At that time it had just one, traditional, redbrick post-war council estate that had been completed by the mid-I950s. As Marcus Kimball was visiting the site of the Middlefield Lane estate, an 'officially sanctioned and unstoppable' programme of modernization was transforming many of Britain's towns and cities. ${ }^{3}$ Whether it was the modernization of town centres, the creation of new towns or new local authority housing estates, the core principles of this transformation were modernist - of comprehensive redevelopment, planned dispersion, and of clean lines - all of which, as we shall see, were to come into effect with the design and planning of Middlefield. The zeitgeist was defined by progress and of things being 'New'. Even in provincial Lincolnshire, as Middlefield's first residents were moving into their new homes, a new, 'ultra-modern' Co-operative store had recently opened in Gainsborough's market place, while the town centre's dense medieval street patterns were being opened up to accommodate a new parade of shops and a new modernist Guildhall. ${ }^{4}$ At the same time, the Gainsborough Evening News celebrated the architecture and planning of the Middlefield Lane estate as 'Something New for Gainsborough'.5 A year after the estate's completion, the News went on to make a feature of an aerial photograph of the estate with the headline 'Take a Look at New Gainsborough'. 6

This article will provide a narrative account of this period in Gainsborough's history by specifically examining the early planning, development, and eventual settlement of Middlefield. The primary source for this will be the Gainsborough Urban District Council's Housing Committee (GUDC) minute books for the years I96I to 1965. From these, we shall see how this relatively small local authority absorbed new architectural and planning principles as it implemented its ambitions for what was

Gainsborough Evening News (GEN), 9 Jul. 1963.

J. Grindrod, Concretopia: A Journey around the Rebuilding of Postwar Britain (London, 20I4), 22.

D. Kynaston, Modernity Britain: A Shake of the Dice, 1959-62 (London, 2014), 265.

4 The new Co-operative store was described at the time as 'an ultra-modern “one-stop” shopping emporium': GEN, 4 Oct. 1963.

Ibid., I9 May 1964.

6 Ibid., 25 May 1965. 
generally viewed as an important new development for the town. The minute books also reveal how the negotiations made between the council and the estate architects reflected contemporary national standards and debates with regard to the ideal population density of the estate (at a time when high-density, high-rise developments were increasingly seen as the solution to the ongoing housing crisis), and to newly-defined standards of space, design, and facilities within the homes themselves as it became apparent that a new, 'modern' way of life was developing in line with increased leisure time and prosperity.

In addition to the minute books, a number of articles from the Gainsborough Evening News will also be employed here to give a popular, social perspective on the progress of the estate as it was being planned and built, and on what the residents felt about the estate once it had been completed. These reports are also interesting because they draw attention to some cultural tensions that emerged in the town as the community struggled to accept the new ideas that were embodied in this very modern and up-to-date development - specifically with a debate that ensued in relation to the naming of the new estate's streets. The catalyst for these concerns was a difficulty in understanding the predominantly open-plan and pedestrianized nature of the estate's layout, which, as we shall see, was based on principles that were wholly new and unfamiliar to the people of Gainsborough.

The apparent difficulties in understanding both the application and significance of these principles have prevailed in recent academic critiques of the post-war council estate, to the point where they have been roundly characterized as a typically misguided, 'utopian experiment' in spatial and social planning. These critiques rarely examine individual estates however, and this article will begin to remedy this with an examination of these principles as they were employed on the Middlefield Lane estate. Further contemporary fears for the loss of old working-class communities at the expense of these new 'suburbanized' estates will then be considered via a number of other Evening News reports that canvassed the expectations of Middlefield's new residents as they began to settle there, both in terms of the older slum housing they had left behind, and in respect of their aspirations and feelings towards their new homes and the estate environment as a whole.

\section{The historiography of the post-war English council estate}

Local authority-built rented housing was a key feature of the post-war, 'Welfare State' reconstruction of British society and culture: between 1945 and I969 four million public dwellings were built - some 59 per cent of all housing built over that period. ${ }^{7}$ This of course produced a number of diverse estate types, from the garden suburb model that was embodied in New Town projects such as those at Harlow and Stevenage for instance, to the inner-city estate that came to be dominated by the high-rise tower block. Almost two-thirds of total public housing built in that period however consisted of fairly traditional two- or three-bedroom houses that were laid out in 'suburban'

M. Glendinning and S. Muthesius, Tower Block: Modern Public Housing in England, Scotland, Wales and Northern Ireland (London, I994), I. 
estates - a model with which the Middlefield Lane estate was almost entirely consistent, with the exception of a limited number of three-storey walk-up flats. ${ }^{8}$

Despite this, the most comprehensive study of the design, politics, economics, and social consequences of the post-war council estate is Glendinning and Muthesius' definitive account of high-rise housing, Tower block (I994). In contrast, a similarly detailed study of low-rise, provincial post-war council estates has yet to be written. This article seeks to begin that process not only for its own sake but also because scholarly work on post-war council housing is still generally quite limited. In order to glean the strands of thinking and analysis that focus on the post-I945 council estate one has to sift through a wide body of work on British housing that first of all tends to look back at least to the end of the First World War. Furthermore, there is also a tendency to conflate both public and private housing, while the subject of housing in general is approached from a variety of academic perspectives: architectural history, the economics and politics of housing policy, sociological studies of community, cultural assessments of suburbanization, to name but a few.

The sole architectural survey of public housing is Harwood and Powers' Housing the Twentieth-century Nation. ${ }^{9}$ As the title suggests however, Harwood and Powers take I9I 8 as a starting point, and the survey on the whole covers both local authority and philanthropic housing. Only one chapter is devoted to post-I945 provincial council estates, but it tends to dwell on vernacular design elements of examples from the immediate post-war years - for instance the council houses designed by Herbert Tayler and David Green for Loddon District Council in Norfolk during the late I940s. Elsewhere, the study of the design of the post-war council estate tends to be subsumed within the broader examination of the ways in which the twenty to thirty years of reconstruction that followed the Second World War saw the establishment of modern architecture in Britain. Esher, Bullock and, more recently, Grindrod all chart the opportunities for innovation and experimentation created by post-war rebuilding, although this is considered more widely in relation to a variety of architectural types, from civic buildings to shopping centres and schools. Council housing is examined but again only in a limited sense where the main focus is on key architectural examples of high-rise, high-density estates in Britain's major cities. ${ }^{\text {IO }}$

To date, Ravetz has provided the only scholarly monograph that focuses solely on council housing and its social and cultural consequences, although it also looks extensively back to Victorian philanthropic and garden city movement origins. ${ }^{\text {II }}$ Ravetz is generally sympathetic towards the social and practical aims of council house provision, but she is also unflinching in pursuing the belief that these aims were almost fatally compromised both by the complexities of state finance and local authority control, and - especially — by over-intellectualized and 'utopian' ideas in architecture and planning. Most recently, Hanley has reinforced those themes more critically by combining downbeat personal reminiscences of childhood on a post-war highrise estate in Birmingham with an account of local and central government housing

8 Ibid., 2.

9 E. Harwood and A. Powers (eds.), Housing the Twentieth Century Nation (London, 2008).

${ }^{10}$ L. Esher, A Broken Wave: The Rebuilding of England 1940-I980 (London, I98I); N. Bullock, Building the Post-war World (Oxford, 2002); Grindrod, Concretopia.

${ }^{\text {II }}$ A. Ravetz, Council Housing and Culture: The History of a Social Experiment (Oxford, 200I). 
policies both before and after the Second World War. ${ }^{\mathrm{I} 2}$ Like Ravetz, Hanley is also sympathetic towards the post-war, welfare state programme of creating housing that was intended to improve people's lives, but in her overall attempt to understand why this programme appeared to fail, Hanley falls back on a number of typically negative tropes - bad planning, poorly designed housing, drabness, uniformity, decay - that unfortunately persist today. ${ }^{\mathrm{I}}$

A comprehensive discussion of the 'problems' that came to be associated with council estates particularly from the I970s onward falls outside of the historical focus of this article, but both Ravetz and Hanley raise fundamental issues with regard to council estate design and layout, and the experiences of the new residents on these estates as they moved from often long-established slum communities. That they both take a generalized, century-wide view on this (Ravetz in particular focuses on interwar estates) however emphasizes the need for a closely historicized account of these issues in relation to a single post-war I960s estate, especially as modernist principles dominated the re-building of Britain during the r950s and I960s.

There are however a number of other, more specialist studies that can assist in this task. Ravetz's study of the home environment from the perspective of both public and private housing throughout the twentieth century provides an extensive account of those aforementioned open-plan, pedestrianized layouts that were applied to council estates like Middlefield Lane from the late I950s onward. ${ }^{14}$ The experience of these newly planned environments is a key element of Clapson's work which crucially shifts the assessment of suburban aspirations and values away from the middle class homeowner and towards the experiences of the working classes as they moved into new town and council estate housing. ${ }^{15}$ Changes in the nature of community and association on these new estates in an era of growing affluence and consumption is more closely analysed at a distinctively local level by Shapely in his study of the re-housing of working-class communities in and around Manchester. ${ }^{\mathrm{I} 6}$

Both Clapson and Shapely essentially provide new, revisionist perspectives on those pioneering studies that emerged in the years immediately following the Second World War, when new local authority housing developments became the focus of a school of sociology that analysed the effects of the uprooting of working class communities from nineteenth-century industrial housing, and their subsequent transfer to suburban council estates and new towns. Young and Willmott's famous study of workingclass Londoners moving from Bethnal Green to suburban council estates in Essex, Family and Kinship in East London, was notable for its largely negative account of broken communities and newly isolated families or increasingly competitive and

${ }^{12}$ L. Hanley, Estates: An Intimate History (London, 2007).

${ }^{13}$ Council estates are popularly dismissed and denigrated today as being singularly unprepossessing places in which to live - see for instance Channel 4's television series Skint (2013) which stigmatized a I96os council estate in Scunthorpe by presenting a community seemingly blighted by dilapidated housing, poverty, ignorance, and neighbours from hell.

${ }^{14}$ A. Ravetz (with R. Turkington), The Place of Home: English Domestic Environments I9I4-200o (London, I995).

${ }^{15}$ M. Clapson, Invincible Green Suburbs, Brave New Towns: Social Change and Urban Dispersal in Post-war England (Manchester, I998); M. Clapson, 'The Suburban Aspiration in England since I9I9', Contemp. Br. Hist., XIV (2000), I 5 I-74.

${ }^{16}$ P. Shapely, The Politics of Housing: Power, Consumers and Urban Culture Manchester, 2007). 
status-conscious cockneys, although Willmott's later study of life in new housing in Dagenham, The Evolution of a Community can be aligned with other, more optimistic studies of the time, such as Cullingworth's study of working-class households moving from Salford to the expanded town development of nearby Worsley during the 1950 . ${ }^{17}$

These sources all allow for the production of further, ever more nuanced accounts of the continuities and changes in practice and experience on specific post-war council estates. The mixed historiography presented here reflects the complex range of motives in the history of public housing that could be philanthropic, utopian, socialist, idealistic, expedient, and sometimes even corrupt. In broad, ideological terms, the post-war council estate has historically been condemned from the left for its paternalism and what has been perceived as an imposition of middle-class values. On the other hand, the post-Thatcher Right came to believe that these estates served only to suppress aspirations and ambition. As such, it is perhaps no wonder that council housing's broader contribution to twentieth-century material culture and workingclass life has not had the attention and historical analysis that it deserves. ${ }^{18}$ We can perhaps begin to address this by extending our understanding of these once-new environments, and of how they were initially experienced, by going back to basics, via a detailed historical consideration of the original factors that lay behind the development of one estate, and of the early expectations and aspirations of its residents.

\section{A 'chance to start house building again': the early planning and development of Middlefield}

On Tuesday 28 February 1961, the Gainsborough Evening News led with the headline 'How Gainsborough can benefit by new Act: Chance to start house building again'. The article that followed explained how a new Government White Paper on Housing in England and Wales had been produced in order to help local authorities build new housing at rents that tenants could afford, by adapting the payment of subsidies more closely to the financial resources of an authority. It was estimated that the Gainsborough Urban District Council would qualify for the higher rate of subsidy ( $f_{24}$ per home). These new subsidies enabled the town to embark on a new programme of council estate building in accordance with the plans for new housing laid out by the Ministry of Housing and Local Government which, at that time, was continuing to ask for priority to be given to building schemes that would re-house families displaced by slum clearance programmes. Eight months later, in October 196I, the Evening News announced that the council had approved, in principle, the layout of a new estate to cover a total of $3 \mathrm{I}$ acres of land off Middlefield Lane, which would accommodate 320 dwellings. ${ }^{\text {I9 }}$

In the immediate post-war years, council house provision was shaped by the standards laid out in the I944 Housing Manual, where estates of 5-10 000 people were

${ }^{17}$ P. Willmott, The Evolution of a Community (London, I963); J.B. Cullingworth, 'Social Implications of Overspill: the Worsley Social Survey', Sociol. Rev. (New Series), VIII (I960), 77-96.

${ }^{18}$ Ravetz, Council Housing and Culture, 3.

19 GEN, I7 Oct. I96I. 
envisaged in three forms: 'open development' for $30-40$ persons per acre; 'inner-ring housing' of 70 persons per acre, that would have narrower frontages, and aligned in longer terraces with the occasional block of 3 -storey flats; and 'central area' housing of IOO-I2O persons per acre that would require developments of mostly highrise apartment blocks. ${ }^{20}$ In its developmental stage, the Middlefield Lane estate fell somewhere between the housing manual's categories of open development and innerring housing. ${ }^{2 \mathrm{I}}$ The 1960 'Gainsborough Town Map' produced by the then Lindsey County Council first proposed low, 'open development' densities of approximately 8 houses per acre for new estates within the town, but by the time the GUDC had approved plans for Middlefield in the autumn of I96I, this had crept up to a proposed Io houses, or approximately 40 persons per acre for a total of 320 dwellings.

On 5 February 1962, the process of planning and constructing the estate began in earnest when the council's architects, Fisher, Hollingsworth and Partners, attended a housing committee meeting to submit their plans for the layout of the estate. By this stage however, the projected number of dwellings required had increased to 370 to include extra housing that was to be designated for the elderly. The project architect, Neil Taylor, told the committee that this resulted in a density of nearly I4 houses, or around 52 persons per acre, and he went on to point out that this could only be achieved 'if building was to take place in an upward direction'. After some discussion, the committee agreed to this in principle, thereby reaching a decision that was to take the design of the estate into new, modernist stylistic realms. ${ }^{22}$

At the same time, the Housing Committee was also considering a report published in I96I by the Ministry for Housing and Local Government entitled Homes for Today and Tomorrow. This report had been drawn up by the Parker Morris Committee (named after its chairman, Sir Parker Morris), which had been appointed 'to consider the standards of design and equipment applicable to family dwellings and other forms of residential accommodation, whether provided by public authorities or by private enterprise, and to make recommendations'. ${ }^{23}$ As a consequence, Homes for Today and Tomorrow essentially concluded that new homes needed more space in order to be more adaptable in response to a rise in living standards and to the changing lifestyles of ordinary people:

a good house or flat can never be made out of premises which are too small. As well as a place where the family can gather together, there must be room in every home for activities demanding privacy and quiet; there must be space to allow for better planned and

${ }^{20}$ Esher, Rebuilding of England, 46.

${ }^{21}$ At this time, the Gainsborough Urban District Council was already making plans that would begin to eventually make Middlefield part of an 'inner ring' for the town via the construction of a ring-road on the eastern edge of the estate as well as a new 'overspill' estate and industrial estates on the fields beyond that — all of which had come to fruition by the mid-r97os.

${ }^{22}$ Gainsborough Urban District Council Committee Minute Book (GUDC), Vol. LXII (I96I-62), Housing Committee Minute No. I377, p. 403.

${ }_{23}$ Ministry of Housing and Local Government: Central Housing Advisory Committee, Homes for Today and Tomorrow (Report of the Parker Morris Committee) (London, I96I), iv. 
better equipped kitchens with room in which to take at least some meals, and for more satisfactory circulation and storage. ${ }^{24}$

The GUDC Housing Committee had already asked the project architects to make suggestions for the design of the houses on the Middlefield Lane estate in relation to the recommendations of the report - for instance that the desirable minimum net floor area of a 2-storey semi or end terraced home for up to four people should be at least $770 \mathrm{sq} \mathrm{ft}\left(7 \mathrm{I} .54 \mathrm{~m}^{2}\right) .{ }^{25}$ At a meeting held on 23 July 1962, Neil Taylor specifically recommended an increase in floor space to take the homes on Middlefield beyond this minimum, but the committee argued that this might result in an unacceptable reduction in the number of new homes the council now required. It was further pointed out that the floor areas of all the proposed houses and flats were either at, or near to, the desired minimum and that this 'should remain as shown on plans already approved by the council'. ${ }^{26}$

Homes for Today and Tomorrow was also progressive in its anticipation of living in a fast changing and increasingly technological society, suggesting that new patterns of living, brought about by the increased use of the television set, more kitchen equipment, growing car ownership, increased varieties of leisure activities and greater affluence, required a radical redefinition of housing design. Taylor eagerly picked up on this and pressed on with more improvements for the homes on the Middlefield Lane estate by successfully persuading the housing committee that they should have an increased number of electrical sockets in order to cater for the potential expansion in the use of domestic electrical appliances, and that each house should be fitted with both an immersion heater and a back boiler system to produce hot water for the home. ${ }^{27}$

Over the following months, the housing committee noted the continuing production and development of the plans and specifications for the estate. In a meeting held on I2 November 1962, it was stated that the construction company, George Wimpey, had approached the council with an interest in the contract for building the estate. By the I96os, Wimpey had come to dominate the local authority house building market, producing up to 18000 council houses a year, and the council readily agreed that the company could carry out the building works on a 'negotiated' basis. ${ }^{28}$ During the spring of 1963 , the council entered into negotiations with the company on the overall cost of the estate until, in a meeting held on I7 June I963, the housing committee agreed to award Wimpey the contract to build ' 327 dwellings, six shops, I community hall and I 43 garages at a cost of $£ 829,007$ '. The contract was scheduled to commence soon after, on 8 July 1963 , with a view to the whole estate being completed by 8 April $1965 .^{29}$

Wimpey council houses tended to be of a fairly traditional design, and of a type that was replicated almost ad nauseam across the country. The look of their houses

${ }^{24}$ Ibid., 9.v

25 http://www.singleaspect.org.uk/pm/ [accessed 3 Feb. 2015].

${ }^{26}$ GUDC, Vol. LXIII (I962-63), Housing Committee Minute No. 365. p. II8. In fact, a 2-bedroomed end terraced house at Middlefield slightly exceeds this with a net floor area of approximately $74 \mathrm{~m}^{2}$.

27 Ibid.

${ }^{28}$ Ibid., Minute No. 802, p. 270.

${ }^{29}$ GUDC, Vol. LXIV (I963-64), Housing Committee Minute No. 322, p. 5I. 
was largely dictated by the company's favoured 'no fines' construction method, and which was used on the Middlefield Lane estate. The external walls of no-fines houses (so named because the concrete used had no added sand, or 'fines') were created by casting concrete in situ and in one operation using reusable wooden or steel shutterings, which were then removed to create the shell of a house. The ground floor was also made of concrete while the first floor used traditional timber joists and floorboards. Interior walls were constructed using a mixture of conventional brick or block work. To weatherproof the structure, the external facade was either externally tiled or pebbledash rendered. Local authorities contracted Wimpey to build thousands of these houses in this manner because they could be erected very quickly - so quickly in fact that when The Gainsborough Evening News reported on the progress of work at Middlefield, it referred to the estate as a 'mushroom town' ${ }^{30}$ As Esher put it: 'given the standard components and the standard layouts [an estate] designed itself ... Only an occasional group of walk-up flats broke the horizontal lines of 2 -storey terraces'. ${ }^{3 \mathrm{I}}$ This was generally true of Middlefield, but some parts of the estate were not quite going to be so standardized - the estate architect had a vision for something much more ambitious and contemporary.

\section{Enjoying the best of both worlds: the design and layout of the Middlefield estate}

The council's contract with Wimpey caused Neil Taylor some concern, which he raised with the housing committee on I2 November 1962. 'A certain amount of architectural work would be saved' by using Wimpey, Taylor argued, but 'the architect's plans' would have to be 'significantly altered to conform to the particular type of design and building construction methods used by Wimpey'. In a conversation with Mr Taylor in March 20I2, he stated that he was 'keen to keep Wimpey at bay' specifically because he wanted 'a more modern estate'. ${ }^{32}$ In the long run however, he had to compromise by allowing Wimpey's more traditional house designs to dominate so that he could concentrate on his stylistically modernist centrepiece of the estate, the complex of shops and maisonettes known as The Precinct, and its connecting blocks of three-storey flats at North and South Parade (Figure I).

Taylor referred to The Precinct as the 'core of the estate'. A detail from a I975 Ordnance Survey map of the estate shows this both in terms of the architectural structure itself, and of the landscaping around it (Figure 2). Architecturally, The Precinct complex consisted of a low-rise 'mega-structure' of connected blocks, simply-lined but with subtle variations in the tile and brick façades, and in the window alignments that echoed the slightly downward slope of the site. 'Link maisonettes' connected the North and South Parade blocks of flats on both sides of The Precinct, and with short tunnels underneath. The surrounding landscape was relatively basic, but for a rural Lincolnshire market town its extensive, formal geometry was ambitious in its likeness to a baroque country house landscape garden, with The Precinct at the centre of the

\footnotetext{
GEN, 10 Sept. 1963.

${ }^{31}$ Esher, Rebuilding of England, $47-48$.

${ }^{32} \mathrm{~N}$. Taylor, telephone interview with author, 23 Mar. $20 \mathrm{I} 2$.
} 


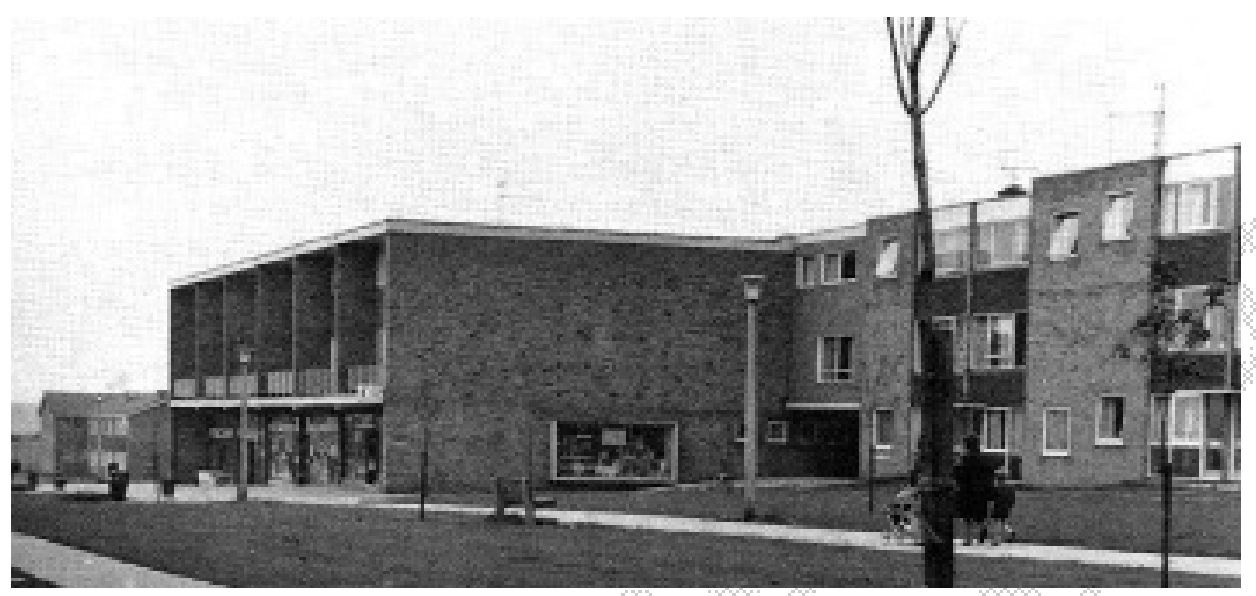

FIGURE 1 The Precinct and North Parade flats, 1967.

Photograph courtesy of the Gainsborough Heritage Association

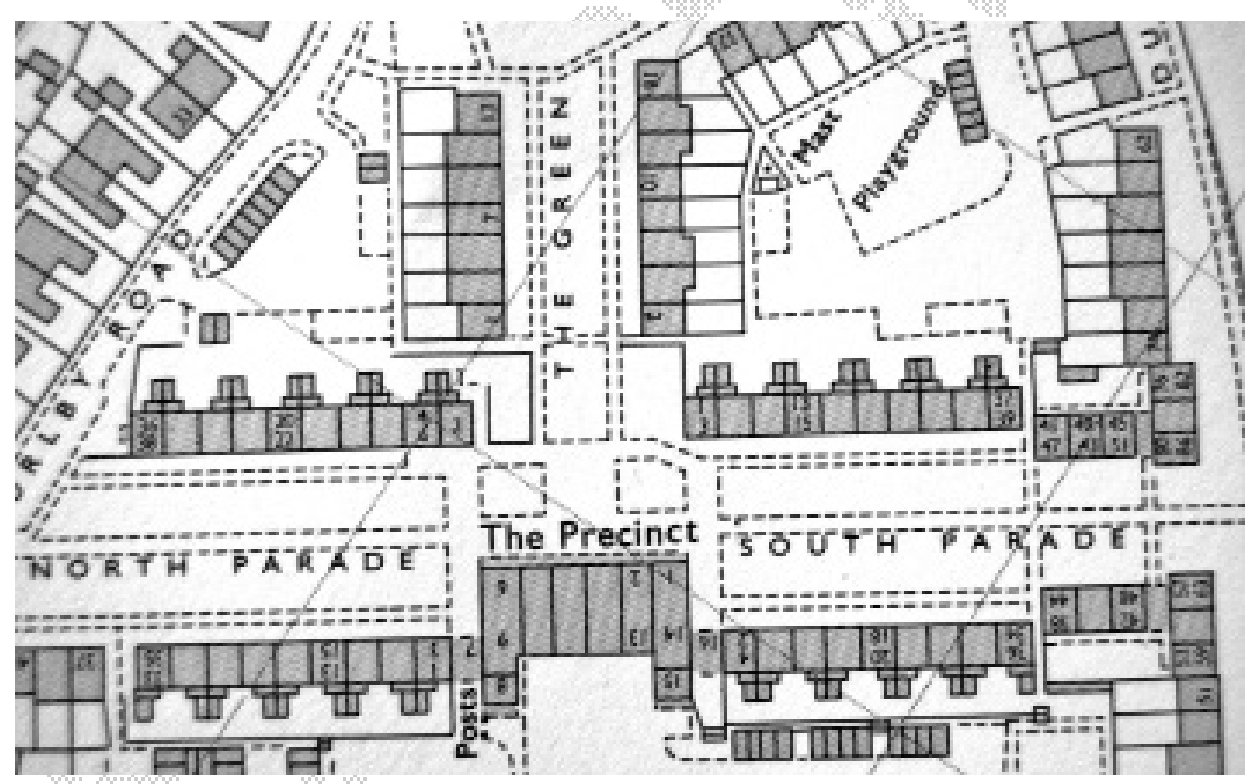

FIGURE 2 The Precinct and its surrounding landscape, 1975.

Crown copyright Ordnance Survey. All rights reserved

estate, and with a prospect of green avenues and footpaths — the 'Parades' and 'The Green' — radiating outwards from it.

This complex formed what architects and planners of the time referred to as a 'neighbourhood centre', which was based on the notion that new estates like Middlefield should be made relatively self-sufficient by providing all the shopping and communal facilities that residents would need on a daily basis, and within walking distance from home. In addition to the shops on The Precinct, Taylor was also aware of the need to forge a sense of community in these otherwise very new environments by providing 
the estate with its own community centre that was situated at the end of the North Parade flats just across from the shops themselves. The other important facet of a neighbourhood centre was that it should also be easily accessible on foot and clearly separated from any traffic, and in this case Middlefield was no exception: the landscape surrounding The Precinct and its environs was almost entirely pedestrianized.

The model for this was known as 'Radburn' planning, so called because it was based on the small unfinished settlement of Radburn in New Jersey, which had been one of a number of experimental housing projects promoted by the Regional Planning Association of America at the time of the Great Depression and President Roosevelt's 'New Deal' programme of social reforms (Figure 3). The Radburn layout has been appropriately described as 'garden city plus motor car', because it was designed to provide dual but otherwise quite separate circulation systems for cars (short cul-de-sac lanes that ran off a limited number of access roads and which would lead to parking at the back, or 'service', side of the houses) and for pedestrians (networks of public footpaths and green spaces kept away from the roads at the front of the houses). ${ }^{33}$ Radburn planning was first acknowledged in this country in a 1949 housing manual, but came to be more widely applied to the design and layout of many English council estates in the I960s, when it was envisaged that personal car use would rapidly increase over the decade. Ever aware of new ideas and precedents, Neil Taylor was keen to adopt Radburn principles to the layout of the Middlefield Lane estate as he began work there in $1962 .{ }^{34}$

As a consequence, Middlefield was planned to accommodate car use but also to minimize the car's intrusion onto what was predominantly meant to be a communal, pedestrianized environment. We can see on the O.S. map of the estate just how similar the layout was to Radburn in that it was essentially served by two access roads: one to the rear of Dunstall Walk, and one known as The Drive which led to the back of The Precinct shops (Figure 4). Along The Drive for instance the car was kept to one side of the houses (or 'round the back', as residents tended to put it) via shorter cul-de-sac service lanes that ran off the access road. On the other side - 'the front' - short rows of houses were grouped around open green spaces (the areas named on the map: Priory Close, Upton Walk, and so on) and with a self-contained, interlinked public system of footpaths. The footpath system made it unnecessary for pedestrians to walk on or across the access roads, giving residents almost complete seclusion from the car.

In recent years, council estates laid out in relation to Radburn principles have been roundly criticized by Alison Ravetz in particular because, she argues, those principles were applied in a diluted, hybrid manner. Ravetz rightly states that a fundamental change here was that the British version of Radburn grouped houses in short rows or terraces rather than in 'superblocks' consisting of a small number of pairs. ${ }^{35}$ This was perhaps understandable, given the economies of scale and the ongoing urgent need for housing in the early I960s, but Ravetz also suggests that these 'Radburn-type'

${ }_{33}$ Ravetz, Council Housing and Culture, ro3.

34 Taylor was so keen on using Radburn principles for the Middlefield Lane estate that he persuaded his wife at the time to accompany him on a Sunday drive from Gainsborough to Coventry to see a new council estate there that had been influenced by Radburn (Taylor, telephone interview with author, 23 Mar. 20I2).

35 Ravetz, Council Housing and Culture, ro3. 


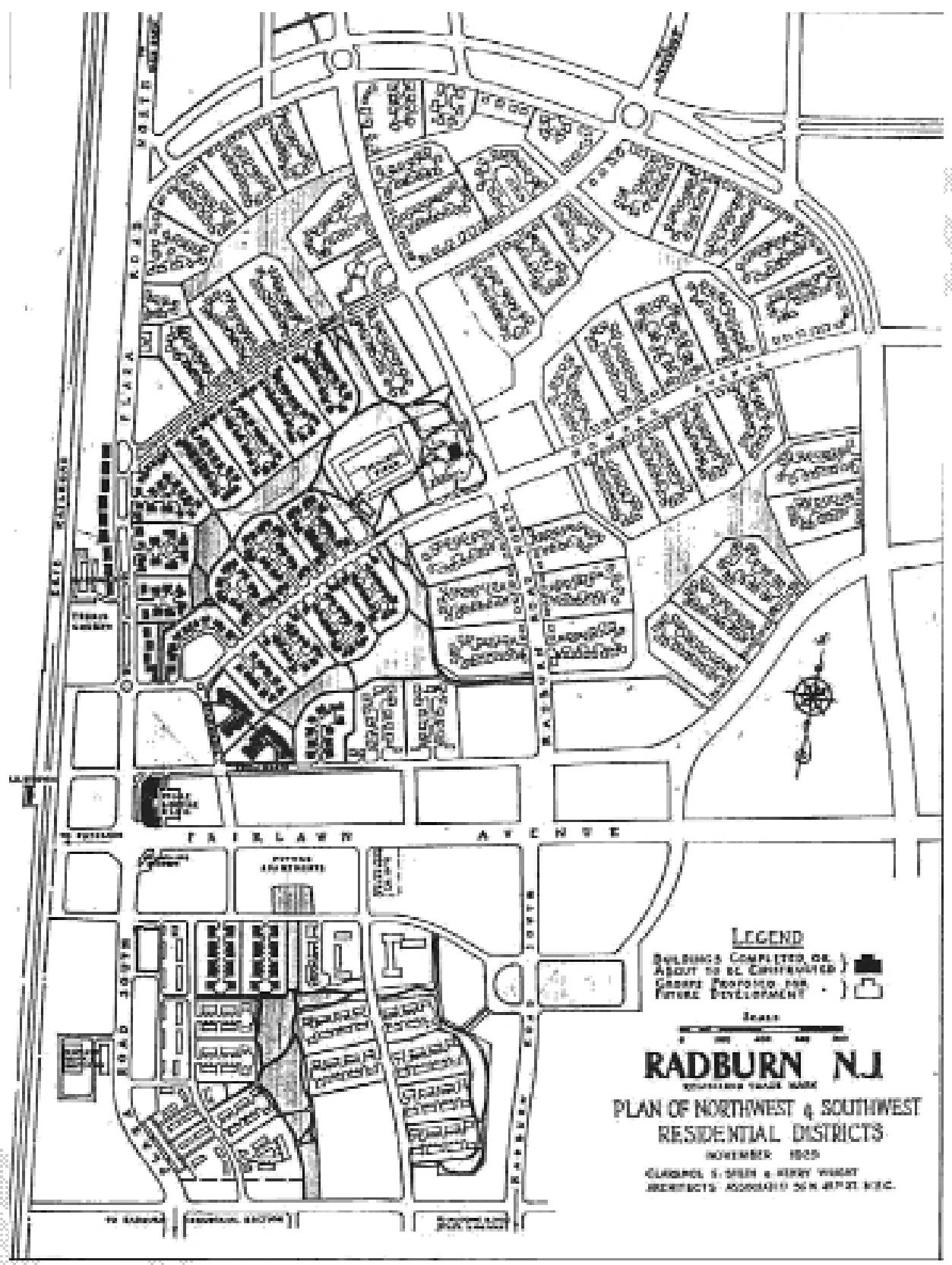

FIGURE 3 The Radburn Estate, New Jersey.

layouts fundamentally did not separate the pedestrian from car access routes rigorously enough, in that houses could still generally be accessed by public footpaths at the front and back. At the same time, the cul-de-sac service roads led to garage courts that were largely located out of sight and at an inconvenient distance from the house. ${ }^{36}$

${ }^{36}$ Ravetz, Place of Home, 36-37. 


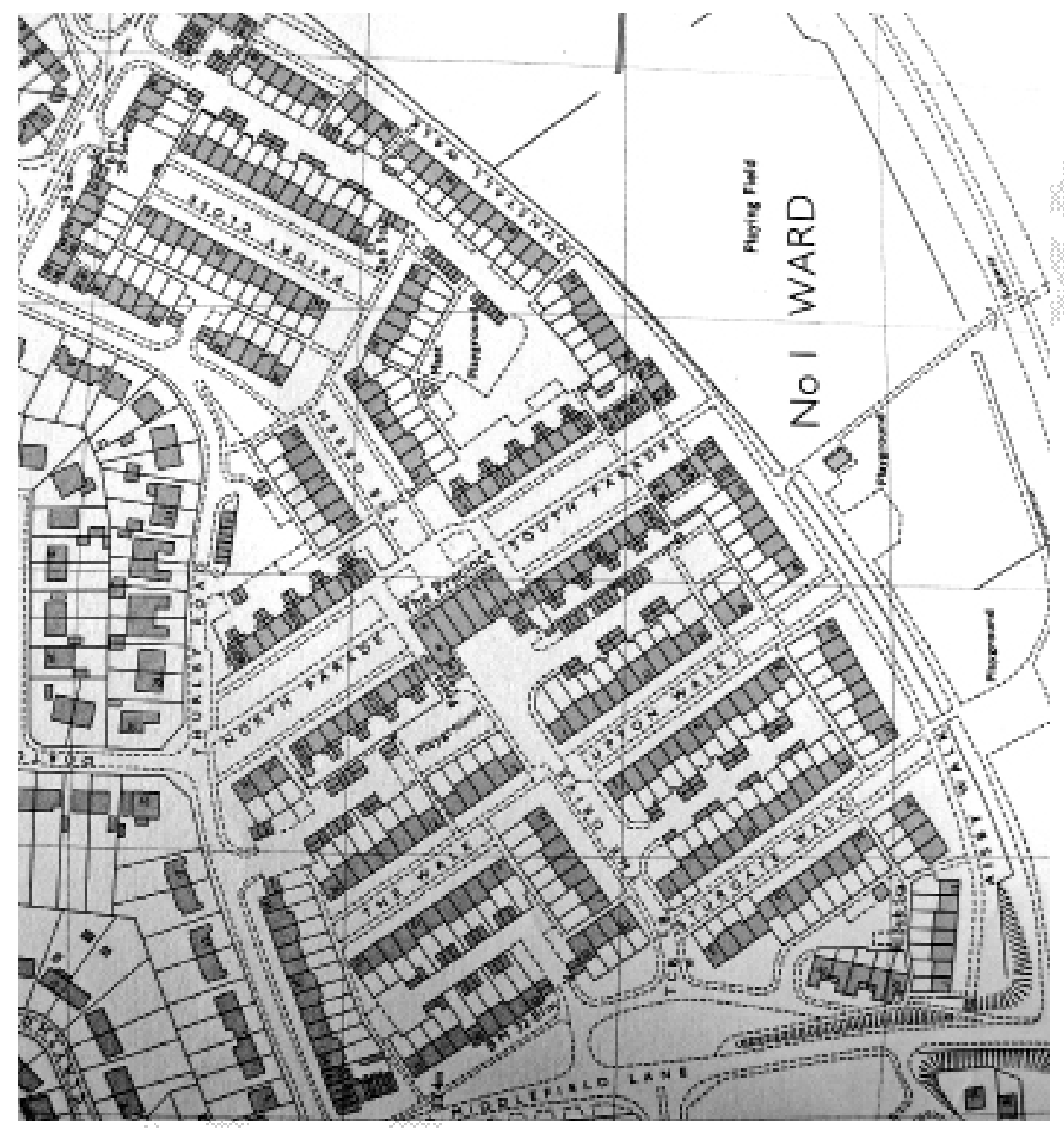

FIGURE 4 The Middlefield Lane estate, 1975.

Crown copyright Ordnance Survey. All rights reserved

Ravetz's criticisms lack close analysis of any one particular 'Radburn type' estate but, in the case of the Middlefield Lane estate, it can be argued that Radburn principles were, in general, carefully and correctly applied. The estate was indeed largely made up of a number of short, terraced blocks of houses but all the public footpaths were located only at the 'front' of the house and around wholly pedestrianized green spaces. Ravetz suggests that the distancing of garage courts away from the houses was partly due to official reluctance to foresee the growth of car ownership amongst council tenants, but this was certainly not the case at Middlefield where the GUDC had allocated a total of I43 garages to around 320 homes (roughly a $40 \%$ allocation in relation to an average of $10 \%$ in the New Towns of the I950s). ${ }^{37}$ Notably, these garages were also

${ }^{37}$ Esher, Rebuilding of England, 48. 
set out along the cul-de-sac service lanes directly at the back of the houses. The car was not able to drive up to the door as perhaps British suburban conventions dictated but could still be garaged or parked close by at the back of the house, by the back gate. The back therefore, became the 'service' side of the home, leaving the open, green spaces at the front to function as safe and potentially sociable spaces.

Although Radburn-style layouts were being put into effect on a number of new council estates across the country at this time, this was more or less unheard of in Gainsborough itself and it caused some disquiet as the townspeople's notions of tradition and the planners' drive towards modernity clashed. As work progressed on the construction at Middlefield, a housing committee meeting held on 9 September 1963 recorded that the committee had received a letter from the Lincolnshire Local History Society (now known as The Society for Lincolnshire History and Archaeology) asking for local historical associations to be kept in mind when naming the new streets on the estate. Accordingly, the committee instructed the clerk to reply asking for suggestions. ${ }^{38}$

Meanwhile, the estate architects attempted to impose control over their more modern vision for the estate via a letter to the housing committee dated 30 September that was written 'with regard to the problems arising in connection with the naming of roads on an estate designed on Radburn principles'. The letter went on to assert that the council should approve the names they had already suggested. The 'problems' lay in the fact that the only 'streets' in any conventional sense were the two access routes into the estate which was dominated in any case by what were, in the planning stages at least, a numbered series of housing 'blocks' that were arranged, Radburn-style, around the open green spaces and the system of footpaths. With the exception of three 'blocks' that were planned to be named after the nearby villages of Upton, Kexby, and Heapham, the architects wanted crisp, sophisticated, and modishly functional names: 'The Walk', 'North Parade', 'South Parade', 'The Lawn', and 'The Precinct'. ${ }^{39}$.

The debate surrounding these names rumbled on into November, when an edition of the Gainsborough Evening News led with an article entitled 'Council Name New Estate Roads'. Despite this headline, it seemed that this situation had still not yet been fully resolved, and the Evening News did not hold back in its condemnation of the current situation:

With the construction of this completely new estate, costing in all nearly $£_{\mathrm{I}}$ million, the opportunity was there for the council to reflect the quality and importance to the town of this development in the names of the streets but there would seem to have been a singular lack of imagination in the titles approved, without comment, by the whole council. ${ }^{40}$

A week later, the Evening News followed this up with a report on a letter it had received from four townspeople who preferred to remain anonymous. The letter complained that the names the council had adopted were 'very confusing' and that 'no imagination at all

GUDC, Vol. LXIV (1963-64), Housing Committee Minute No. 473, p. I55.

39 Ibid., Minute No. 663, p. 222.

$4^{\circ}$ GEN, I2 Nov. I963. 
has been used'. The correspondents then went on to put forward their own suggestions that tended to be based on both past and recent-past glories - Aden Drive, Balmoral Close, Elizabethan Walk, Gwynne Avenue, Lancaster Drive — and which perhaps served only to polarize the situation in relation to the architects' preferences that were certainly more up-to-date, even if they were somewhat detached in nature. ${ }^{4 \mathrm{I}}$

The townspeople's suggestions demonstrate a somewhat ingrained conservatism and a distinctly suburban flavour, which was clearly at odds with a local authority that, in line with so many others, was determined to engage with the 'unstoppable' pace of change that the new decade called for. Nevertheless, the 'problems arising in connection with the naming of roads on an estate designed on Radburn principles' persisted when it emerged in December that the clerk of the council had been approached by the local GPO head postmaster, who felt that difficulties in correctly delivering mail on the new estate 'might arise in view of the similarity of road names in the area'..$^{42}$

The planners of the I960s wrote breezily and proactively about the use of Radburnstyle layouts for council estates: 'What we can do in housing schemes is minimise [the car's] visual intrusion; and, by separating it as completely as possible from pedestrians, keep it from making life dangerous and unpleasant'. All was for the communal good: 'Only then can motorists and pedestrians, who are also sometimes the same people, enjoy the best of both worlds'. ${ }^{43}$ This is what Neil Taylor wanted to achieve for the Middlefield Lane estate but it was clearly causing some considerable concern from the outset. Ravetz again argues that the fundamental problem with the Radburn type of layout was that it made it 'difficult to distinguish the backs from the fronts of houses: in a conventional sense they had neither', and that the communal, open plan layout of the pedestrianized areas caused further confusion, so much so that 'Signs with arrows pointing to runs of odds and evens had to be provided ... Visitors, even residents themselves had difficulty locating addresses'. ${ }^{4}$ This was perhaps at the back of the mind of Gainsborough's head postmaster when he wrote to the GUDC with his concerns and, perhaps as a consequence, signs indicating odds and evens were indeed provided on the Middlefield Lane estate, even though the arrangement of the blocks of houses still essentially conformed to tradition, with odds on one side and evens on the other, except with open green spaces separating the two sides rather than a through road (Figure 5).

The crux of these 'problems' lay in notions of convention and of what was 'the front' on these estates. In a British Radburn-type layout, 'cars could not be brought up to the front door', and so this 'breached the accepted codes of propriety'. ${ }^{45}$ As we have seen, the former was certainly true of Middlefield, where the fronts of houses gave out onto the open green spaces and footpaths, while the 'backs' led to the access

4I GEN, I9 Nov, I963.

${ }^{42}$ GUDC, Vol. LXIV (1963-64), Housing Committee Minute No. I004, p. 35r. In the end, several amendments were made, for instance to change Heapham Close and Heapham Walk into Priory Close and Dunstall Walk respectively, while Middlefield Walk became Aisby Walk. This time, the re-naming of the estate's places did have more of a local-historical flavour, employing both the names of nearby deserted medieval villages ('Dunstall' Walk) and of now-disused World War Two airfields ('Sturgate' Walk), and so it is probable that this was finally resolved with regard to the suggestions made by the Lincolnshire Local History Society back in October.

${ }^{43}$ Ministry of Housing and Local Government, Cars in Housing I: Some Medium Density Layouts (London, 1966), I.

${ }^{44}$ Ravetz, Council Housing and Culture, I03.

${ }^{45}$ Ravetz, Place of Home, 37. 


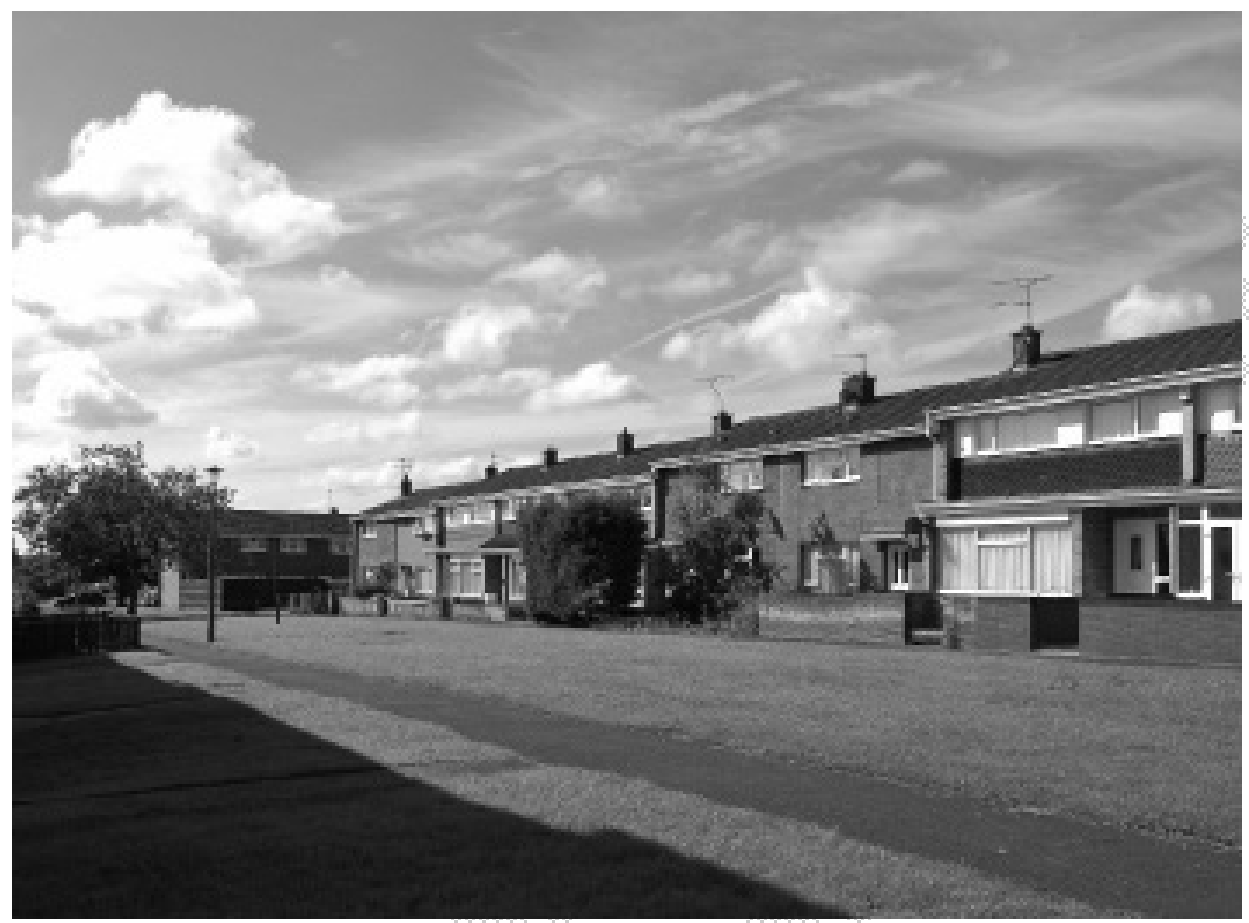

FIGURE 5 The Walk, Middlefield Lane estate, 2012. Photograph by author

roads and the service areas. But the situation here with regard to a 'conventional' street however was merely reversed. Rather than breaching the accepted codes of propriety, it seems that this type of layout actually enhanced them. The general improvement in housing conditions and an overall way of life that estates like Middlefield afforded to the working classes in particular was embodied in the design of these estates and a new understanding of a 'front' and a 'back'. A I96I study of manual workers by the sociologist Ferdynand Zweig concluded that improvements in housing conditions was the most potent factor in the transformation of working class life, and he noted the symbolic social changes that the new council estates were bringing about. As one worker put it: 'In the previous house the front door was never meant to be used: we had a settee across it. Everyone, including the postman, called at the back door. Now it is different. We've moved to the front'. Zweig interpreted this as 'representing a shedding of a sense of inferiority and a replacement of the 'kitchen mentality' by the 'living-room mentality', but he is also inadvertently reporting a change that was, to some extent, brought about by the Radburn layout. ${ }^{46}$

${ }^{46}$ F. Zweig, 'The Worker in an Affluent Society: Family Life and Industry' (I96I), quoted in J. Burnett, A Social History of Housing I8I5-I985 (Oxford, I993), 284. 


\section{'We have a good home, good friends and we shall always be happy up here': completion and settlement}

The vexed issue of names with regard to the Middlefield Lane estate reached a topical but perhaps overextended conclusion when a GUDC housing committee held on 9 December 1963 briefly considered calling the estate 'The Kennedy Estate' as a tribute to the recently assassinated US president. Sensibly perhaps, the committee recommended that 'no action be taken on this suggestion but that the use of the late President's name be borne in mind when the naming of future recreation grounds or housing estates is under consideration'. ${ }^{47}$ On I3 January I964, the estate architect, Neil Taylor, was able to inform the committee that the handing over of the first block of houses would take place by the beginning of February as originally promised..$^{8}$ One month later, the committee noted 'steady progress' on this as four 2-bed, and three 3 -bed houses were officially handed over to the council on 5 February I964. ${ }^{49}$ By this time, the committee were making arrangements to welcome the new tenants onto the estate, initially by allocating seven of the first forty completed houses to 'key workers' who were attached to the two main employers in Gainsborough, the engineering firms Marshall and Company and Rose Brothers Ltd, as well as employees of the Central Electricity Generating Board, and the Yorkshire Electricity Board. Twenty more of the forty houses were allocated to those who had opted to move from the town's slum areas, and thirteen were for 'General Needs'. ${ }^{\circ}$

An indication of how the GUDC was taking seriously the promotion of the new estate as an up-to-date form of living came when a general council meeting held on 3 February I964 agreed to grant the Gainsborough Co-operative Society the use of one house on the estate for 3 weeks in order to fully furnish it with the latest styles as a 'showhouse'. ${ }^{\text {I }}$ This however was clearly extended to the time when the first residents were finally able to move onto the estate in early May. The Gainsborough Evening News of I2 May I964 made a feature of a family who were 'collecting the keys' of the show house itself on Monday I8 May: 'A family of four are counting the days to when they will be leaving their present home, a two-up, two-down terrace house in Popplewell's Row ... and moving to a new council house on the Middlefield Lane estate'. ${ }^{22}$

Local press coverage of new developments such as this generally tended to be positive, 'relatively seldom questioning the need to embrace the tide of modernity'. ${ }^{53}$ In the case of this article, the Evening News was no exception, going on to pointedly explain just why slum clearances were necessary at this time: the house this family was leaving behind had 'no modern conveniences, no bathroom, no larder in which to keep food fresh and only one cold water tap'. Any food 'left from one meal to another has to be thrown away as there is no larder [and] because of the damp'. The damp also meant that some wallcoverings had to be replaced every few months, and

\footnotetext{
47 GUDC, Vol. LXIV (1963-64), Housing Committee Minute No. I007, p. 352.

${ }^{4} \mathrm{Ibid}$., Minute No. II 84 , p. 4IO-II.

${ }^{49}$ Ibid., Minute No. I375, p. 503.

${ }^{5}$ Ibid., Minute No. I347, p. 469.

51 Ibid., General Council Meeting Minute No. I329, p. 398.

52 GEN, 12 May 1964.

${ }^{53}$ Kynaston, Modernity Britain, 29I.
} 
the kitchen scullery looked onto 'a dreary back lane', empty boarded up houses and 'signs of decay'. The article went on to state that the family would be paying a rent of $£_{2} 6 \mathrm{~s} 5 \mathrm{~d}$ for their new home, instead of the I4s for the old one. This represented a considerable difference but the family thought that it would be 'worth every penny': the two children, aged I 2 and II were 'very excited' about moving into their new home and the parents were 'thrilled at the prospect of having a modern up-to-date kitchen with a pleasant outlook'.

This particular 'show house' was situated on the edge of the new estate on Heapham Road, but the majority of the residents on Popplewell's Row were allocated homes elsewhere on Middlefield at nearby Dunstall Walk. A comparison between those listed as being resident on Popplewell's Row in the 1962 Caldicott's Directory for Gainsborough and District and those found on Dunstall Walk in the 1965 edition highlights the manner in which people were re-housed from slum areas. A group of ro residents were placed in two blocks of new houses on Dunstall Walk in almost exactly the same order as they had been on Popplewell's Row, and therefore with the same neighbours as before. Recent historical critiques of post-war council housing have tended to perpetuate the fears originally raised by the likes of Young and Willmott with regard to the negative communal and psychological impact of slum clearance schemes - Hanley for instance argues that post-war housing policies were 'insistent on breaking up poor, yet cohesive, 'slum' communities and dispersing them to faraway estates'. ${ }^{4}$ The way the Popplewell's Row community was transferred onto Dunstall Walk however can be viewed now as a simplistic, but rational attempt to preserve the former community by keeping old neighbours together as they moved up to the new estate.

By the time the new residents were moving onto the Middlefield estate however, newer sociological surveys were, in any case, finding that slum communities were being 'reborn' in 'almost identical form' on the new estates, with 'local networks of neighbours - people living in the same streets who help each other, mix together and are on easy-going terms'. ${ }^{55}$ Peter Shapley has recently noted that until the I960s, local authorities had 'no conception of consultation' with respect to the needs of the tenants of these new estates, arguing that this began to change later on in the decade. ${ }^{56}$ An inkling of this can be detected in the fact that those who were being re-housed on the Middlefield Lane estate had a choice as to where they wanted to live: when one new resident complained that 'Before I came up here I knew all my neighbours very well, but here I don't know anyone', the GUDC's Housing Manager responded by saying that all prospective tenants had a choice between being re-housed 'en-bloc' with their old neighbours (which is what clearly happened on Dunstall Walk) or individually over the estate (which presumably is what happened with the family that moved into the show house on Heapham Road). ${ }^{57}$

If anything was 'insistent' about this process, it was the ongoing necessity to move people out from the slum conditions described in the Evening News article above, and into a new, modern home. In common with other new council estates across the

54 Hanley, Estates, I29.

55 Willmott, Evolution of a Community, I09.

${ }^{56}$ Shapely, Politics of Housing, 30.

57 GEN, 29 Dec. I964. 
country, Middlefield gave many of its residents the first experience of having their own private garden space, a fitted kitchen, a TV aerial socket and, most importantly, a private and indoor toilet and bathroom with a hot water supply. Overall, the estate contained a variety of house types - mainly 3- and 2-bedroom, 2-storey houses, and a smaller proportion of 3- and 2-bedroom, 3-storey maisonettes and flats. The houses were attractive and unpretentious with either tile hung or pebbledash frontages, and they were generally laid out in short terraced blocks.

It was suggested around this time that these blocks could be made up to a maximum of seven houses 'with good effect', but if that number was doubled then they were 'apt to become monotonous'.$^{5}$ The need to maintain density on the Middlefield Lane estate while keeping it essentially low-rise in character meant that that 'good effect' was stretched at times with terraced blocks of some 8 to I2 houses, but these were nevertheless set out in 'courts' around the fully pedestrianized green spaces. The exception to this was Dunstall Walk, which consisted of a broken 'terrace' of 29 houses in total. These however were set out in four separate blocks of six, four, twelve, and seven houses respectively, and each block was set at a slight angle away from one another. Any monotony however was dispelled by the grand, lengthy sweep of the 'walk' itself, and by the fact that Dunstall Walk was on the very edge of the estate, where each house had a view onto open countryside.

Towards the end of 1964, the Gainsborough Evening News led with an article entitled 'The Likes and Dislikes of a New Estate: Middlefield Lane residents have few complaints'. ${ }^{59}$ According to the article, Middlefield was a 'nicely laid-out, compact, estate' and, in general, the new residents there seemed to agree. After talking to around 50 residents on the estate, it was found that 'Top of the list' of 'likes' was the 'fresh-air feeling', as one woman put it, while 'the biggest bone of contention' was the lack of an adequate bus service into the town. One of the frequent criticisms lobbied at new council estates back then was that residents could feel isolated from the hubbub of urban life and its amenities because many of these estates tended to be built on greenfield land on the very edges of towns and cities. Architectural critics such as J.M. Richards in particular lamented the suburban character of new council estates and the New Towns for being far too spacious with their over-large expanses of greenery, long walks and 'lavishly' wide road widths. Richards recognized that such spaces were a 'reaction against the overcrowded Victorian industrial town', but he also argued that they were in danger of 'marooning the unhappy housewife on the distant rim of their sentimental green landscapes ... cut off from the neighbourliness of closely built-up streets'. ${ }^{6}$

Richards would have no doubt criticized the fact that the Middlefield Lane estate was situated on the very edge of Gainsborough about a mile and a half away from the town centre as well as, perhaps, the suburbanized sentimentality of a stroll along the semi-rural, 'distant rim' of Dunstall Walk. This hostility towards the 'sentimental green landscapes' of mass, suburbanized council housing was underpinned by the

${ }^{58}$ F. J. Osborn and A. Whittick, The New Towns: The Answer to Megalopolis (London, I969), 256.

59 GEN, 29 Dec. 1964. Shapely suggests that the civic culture of the time provided a 'network of unspoken values, norms and patterns of behaviour' (Shapely, Politics of Housing, II). The local press also tended to be similarly consensually orientated, although, and as we have seen with the naming of places on the estate, the Gainsborough Evening News was not necessarily afraid of raising qualms in respect of change in the town.

${ }^{60}$ J. M. Richards, 'Failure of the New Towns', Architectural Review, Jul. 1953, 32. 
wider fear that the dispersal of 'poor, yet coherent' slum communities across the open spaces of the new estates would also somehow foster the demise of working-class communal and cultural identity. Recent, revisionist studies however have argued for the adaptable and essentially suburban mind-set of those who moved from the slums: in particular that they clearly understood that moving onto a new council estate meant both a move 'up' and a move 'away', which was especially welcomed by young couples who wanted to put some distance between themselves and the sometimes over-close bosom of the extended family or long-established communities. ${ }^{61}$

At Middlefield, one 'mother of very young children' expressed her long-term commitment to life on the estate by stating that 'she could think of few better places for her children to grow up', and it was noted how the pedestrian green areas will 'come as a boon to the mothers who can now safely allow their children out to play'. Another resident professed to be 'amazed' at the views of open countryside that his flat gave him, while any sense of isolation that the situation of the estate might have caused was soon to be remedied as The Lincolnshire Road Car Company planned to create a new route into town via the estate, with extra buses at peak times. Overall, 'the majority of the residents' were 'full of praise for their bright new homes', especially in comparison to the 'down-town slum areas'. There were small, isolated teething troubles with the houses themselves - some doors were found to be sticking, and some fittings had been left 'damaged by workmen' - and contractors were still 'tidying up the site and grassing certain new areas' but a resident of the North Parade flats summed the situation up thus: 'I think it's all rather wonderful. We have a good home, good friends, and we shall always be happy up here. The Council ... have done a very good job' ${ }^{62}$

The 'bright new' life that the Middlefield Lane estate offered its residents was exemplified on Saturday 27 March 1965 when Pat Phoenix, aka 'Elsie Tanner' from Coronation Street, came all the way from 'Wetherfield' to Gainsborough to officially open the block of shops on The Precinct. The modernist architectural style of The Precinct was highly innovative for this small and still very provincial Lincolnshire market town and it was an important development for the Gainsborough Urban District Council's image as a modern, forward-thinking, local authority. That the council managed to secure one of the biggest television stars of the time to visit the estate was, in itself, a measure of the civic pride that the council felt in relation to the estate's development and completion. A flavour of that momentous occasion, and of these 'go-ahead' times can be gleaned from the Gainsborough Evening News, which reported the actress's visit thus:

Hundreds of enthusiastic schoolchildren and townspeople gathered to give Miss Pat Phoenix ('Elsie Tanner') a real Gainsborough welcome on Saturday when she opened the Parkhill Beer, Wine and Spirit Off-licence shop on Gainsborough's newest housing estate off Middlefield Lane. Miss Phoenix, well-known for her part in the twice-weekly television feature 'Coronation Street', arrived among a wildly cheering crowd with her manager, Mr. Bill Nadin.

${ }^{61}$ Clapson, 'The Suburban Aspiration', I59.

${ }^{62}$ GEN, 29 Dec. I964. 


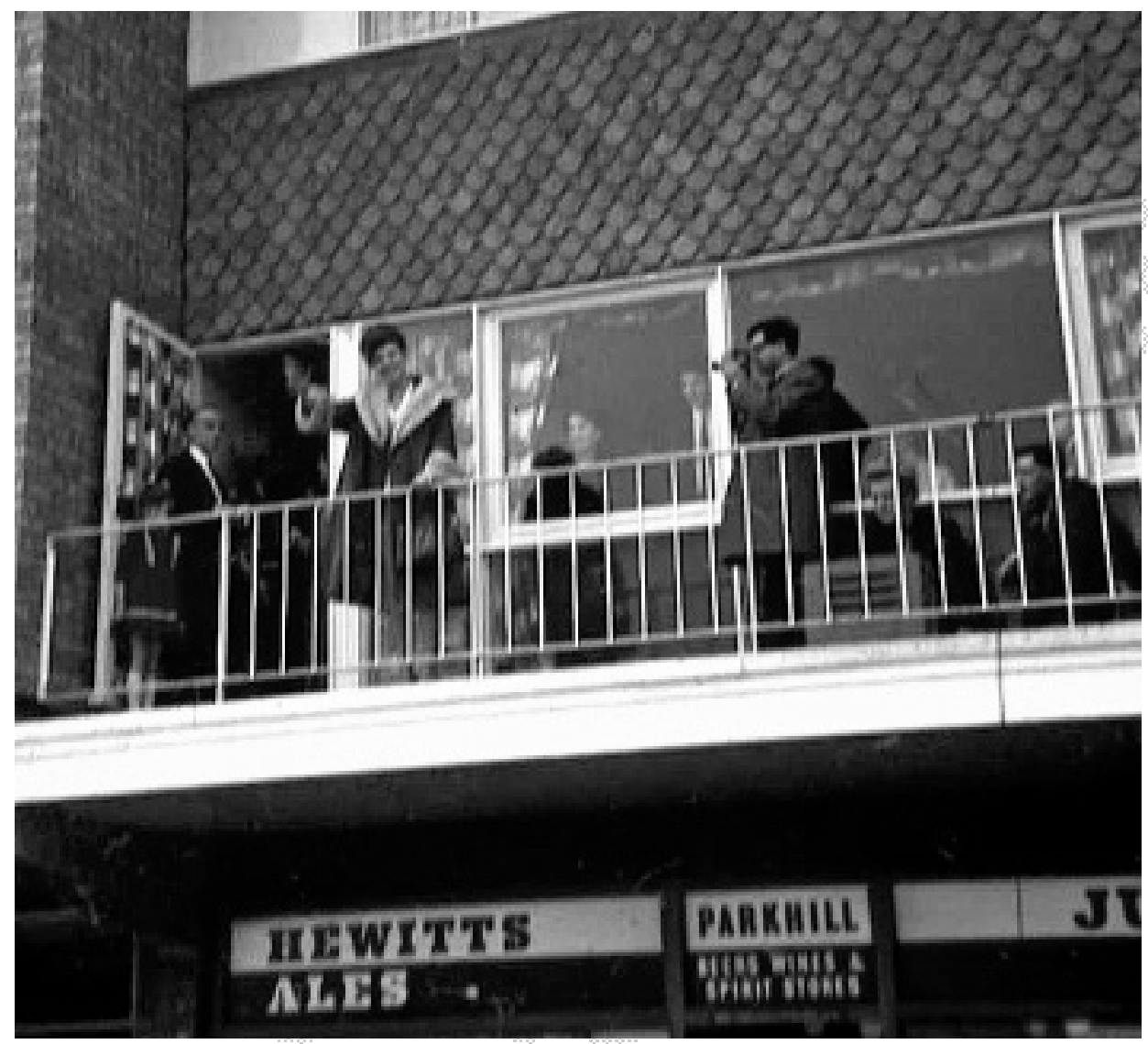

FIGURE 6 Pat Phoenix at The Precinct, March 1965.

Photograph courtesy of the Gainsborough Heritage Association

After a quick sip of champagne and a word with Mr. Ernest Friend (proprietor of the shop) and his wife, Pat was again out speaking to the crowd. They loved every minute as she cut the ceremonial blue ribbon and was presented with a bouquet by eleven-year-old Miss Marlene Andrews, of 27 South Parade, Gainsborough.

In vain her police escort tried to control the milling crowd as autograph hunters pushed forward, and Miss Phoenix spent some time signing ... More cheers went up as she went out on the balcony above the shop to address the crowd once more. ${ }^{63}$

The sense of excitement that must have been felt by the 'enthusiastic' and 'wildly cheering crowd' is made evident by this photograph which shows that very moment when 'Miss Phoenix' came out onto the balcony of the maisonette above the offlicence (Figure 6).

The cultural historian, Patrick Wright, once lamented that British history has treated the whole period of the welfare state as if it was an entropic disaster that

${ }^{63}$ GEN, 30 Mar. I965. 
had reduced the true British people to abject creatures of a failing social democracy'. ${ }^{64}$ There was nothing 'abject' however about the 'wildly cheering crowd' that excitedly gathered outside The Precinct to see Pat Phoenix; on the contrary, the occasion paints a picture of a people who were relishing their new environment and the new and exciting opportunities it had gave them. On the other hand, recent research on similar communities across the midlands has shown that this new world of celebrity and consumerism only had a marginal impact upon customary social mores, where traditional patterns of restraint, neighbourliness and respectability, 'far, far removed from the facile images of the I960s', continued to underpin everyday life. ${ }^{65}$ Despite the trappings of a celebrity visit to Middlefield, and the allure of the range of shops that could be found on The Precinct (a launderette, a newsagent, a supermarket, a TV and Radio rental shop, and the off-licence), the family who had moved into the estate's 'show house' for instance were not letting themselves be carried away by all of this: while they admitted that they were planning to buy some new furniture for their home, they were equally pleased with the existing décor the show house gave them because it meant that 'they would not have to spend anything on interior decoration for a very long time'. ${ }^{6}$

The provision of badly needed, new, local authority-built rented housing was, of course, one of the cornerstones of the welfare state. The 'council estate', as it became known, can therefore be viewed as a symbolic example for any narrative of a 'failing social democracy' in Britain. In common with many other post-war council estates, the social and physical fabric of the Middlefield Lane estate deteriorated severely from the late I970s onward, not because of the way it was planned or managed, but because Gainsborough as a whole suffered badly from the economic downturn of that period when the town's two long-established main employers both closed causing mass redundancies. But in its time, the Middlefield Lane estate clearly gave the people of Gainsborough a chance to live in a good, modern home in a thoughtfully planned, spacious and pleasant estate. There is more work to be done on the history, the design, and the social impact of estates like Middlefield but it is hoped that this article has gone some way to demonstrate that they have a rich and meaningful history that is worth researching and chronicling, if only to counteract the persistent view that they are emblematic of a post-war social-democratic experiment that was always set up to fail.

\section{Notes on contributor}

Dr Ian Waites, University of Lincoln, School of Architecture and Design, College of Arts, Brayford Pool, Lincoln LN6 7TS, UK. Email: iwaites@lincoln.ac.uk

${ }^{64}$ P. Wright and J. Davies, 'Just Start Digging: Memory and the Framing of Heritage', Memory Studies, III (20I0), I98.

${ }^{65}$ Kynaston, Modernity Britain, I64; M. Tebbutt, 'Imagined Families and Vanished Communities: Memories of a Working-class Life in Northampton', Hist. Workshop J., LXXIII (20I2), I6I; R. Watkiss Singleton, 'Old Habits Persist: Change and Continuity in Black Country Communities: Pensett, Sedgley and Tipton, I945c.1970' (University of Wolverhampton, PhD thesis, 20I0).

${ }^{66}$ GEN, I2 May I964. 


\section{Author Query}

Journal title: $\mathrm{MDH}$

Volume and issue: $\quad 40-2$

Article title: Middlefield: The Development of a Provincial Post-World War

Two Council Estae in Lincolnshire, I960-1965

Author name: Ian Waites

QUERY NO. QUERY DETAILS

I Please confirm running head is correct.

$2 \quad$ Please expand GPO.

3 Please confirm inserted quotation marks are correct. 